\title{
Evaluating Anaerobic Digestion Technology in Reducing the Quantity of Solid Waste: Case of Kigali Dumpsite
}

\author{
Nikuze Marie Joselyne',2, Muthumbi Waweru1, Ayub N. Gitau1, Uliho Alphonse, \\ Munyensanga Patrick ${ }^{4}$ \\ ${ }^{1}$ Department of Environmental and Biosystems Engineering, University of Nairobi, Nairobi, Kenya \\ ${ }^{2}$ Department of Civil, Environmental and Geomatics Engineering, University of Rwanda, Kigali, Rwanda \\ ${ }^{3}$ Key Laboratory of Industrial Biotechnology, Jiangnan University, Wuxi, China \\ ${ }^{4}$ Department of Mechanical Engineering, Diponegoro University, Semarang, Indonesia \\ Email: nikuzemariejoselyne@yahoo.fr
}

How to cite this paper: Joselyne, N. M., Waweru, M., Gitau, A. N., Alphonse, U., \& Patrick, M. (2020). Evaluating Anaerobic Digestion Technology in Reducing the Quantity of Solid Waste: Case of Kigali Dumpsite. Journal of Geoscience and Environment Protection, 8, 204-220.

https://doi.org/10.4236/gep.2020.85013

Received: June 5, 2019

Accepted: May 22, 2020

Published: May 25, 2020

Copyright $\odot 2020$ by author(s) and Scientific Research Publishing Inc. This work is licensed under the Creative Commons Attribution International License (CC BY 4.0).

http://creativecommons.org/licenses/by/4.0/

(c) (i) Open Access

\begin{abstract}
Biodegradable organic matter constitutes a great portion of Municipal solid waste and comprises organic material which can be broken down by bacteria like paper, card, green waste, food waste, miscellaneous items with an organic element and fine materials. This paper mainly evaluated the potential of anaerobic digestion technology in reducing the quantity of solid waste destined to the dumpsite in Kigali city. The paper evaluates the viability of using biodegradable waste meant to the land where the biogas is produced and undertaking its cost \& benefit analysis for chemical, physical and biological characteristics of municipal solids waste on anaerobic digestion technology. The quantity of municipal waste generated in Kigali city was used for designing the biodigester required. The paper indicates that the organic waste in Kigali city produces $457 \mathrm{~L} / \mathrm{kg}$ DM of methane and the overall assessed value of methane was $51,384,375 \mathrm{~L}$ with the electricity derived from the methane of $180,873 \mathrm{KWh}$ which is $54 \%$ of the daily demand in Kigali city. The volume of the biodigester was found to be $58,065 \mathrm{~m}^{3}$. Based on the energy recovered, revealed that cities will benefit this research for the population demand for the increased electricity.
\end{abstract}

\section{Keywords}

Anaerobic Digestion Technology, Biodegradable Waste, Kigali Dumpsite, Municipal Solid Waste, Waste to Energy 


\section{Introduction}

Organic waste represents $20 \%$ to $80 \%$ of total municipal solid waste (MSW) stream and it depends on the economic development level of the country. Approximately 25 - 35 million tons of biodegradable waste is produced in the EU every year, and nearly $50 \%$ of that amount includes green waste from public places, parks, and garden waste from households (Adhikari, Trémier, Martinez, \& Barrington, 2010).

Biodegradable waste comprises of the organic material which can be broken down by bacteria like paper, card, green waste (i.e. garden waste), food waste, miscellaneous items with an organic element (furniture, textures, footwear) and fine materials. These materials are the disposal to landfill and result in the production of methane gas as the waste degrades and it is 20 times more potent as a greenhouse gas than $\mathrm{CO}_{2}$ emissions.

Moreover, the emission that arises from manufacturers using virgin materials or energy generation by coal or gas can be avoided by saving greater carbon. Consequently, the legislation implementing the EU landfill is directive progressively restricts the amount of biodegradable municipal waste landfilled so that it may reduce to 35 per cent from 1995 quantities by 2019/20 (Veeken, Hamminga, \& Mingshu, 2005).

Substantial quantities of paper, card and green waste are already recycled but other biodegradable materials, including food waste, are generally left in the residual waste stream. There is a range of options for recovering energy and soil quality enhancement products (organic manure) from the biodegradable fraction of the municipal solid waste (Veeken et al., 2005) and the anaerobic digestion is the controlled decomposition of organic matter in the absence of oxygen.

This digestion is a controlled process of microbial decomposition where under anaerobic conditions a consortium of micro-organisms convert biodegradable organic matter into methane, carbon dioxide, inorganic nutrients and humus (Chynoweth, 1996). The biodegradable organic fraction of MSW includes food remains, yard trimmings, and paper. Besides, this kind of waste is rich in lignocellulose, proteins, lipids, and starch where Lignocellulose is a collective term for three major components of plant tissue include cellulose, hemicellulose, and lignin and about $40 \%$ to $50 \%$ of lignocellulose is cellulose.

In Rwanda, Organic waste management in rural areas is performed by composting and mixing in fields and other types of waste can be reused or buried. In urban areas including Kigali City, solids waste are collected and disposed of in open dumpsite or landfills. In some areas, Solids waste is collected by some cooperatives, organic waste is sorted and recycled into compost and briquettes; this helps to reduce significantly the amount of waste in the environment. Although the solids waste collection has been significantly improved; In general, waste separation at the source is still low and inadequate. In Kigali City, disposal of solid waste poses serious risks to safety and health. Solid waste is disposed of into open dumpsites with simple management techniques that are likely to cause 
both environmental and health effect (RDIS Organisation, 2018).

The option of producing treating the biodegradable organic waste part of the municipal waste by using an anaerobic digestion technology will have enormous economic benefits to the country as a whole as it will contribute to the production of electrical energy through biogas and also contribute to the conservation of soil in the agricultural regions in Rwanda by using the digester slurry as a soil enhancing material (manure). Mainly, there are various other benefits associated with the reduction of solid waste destined for the landfill and open dumpsite. These include:

- More jobs for workers with low and high qualification levels.

- Recovery of costs associated with transportation and tipping fees.

- Savings in waste management costs due to reduced levels of final disposal.

- Resources augmentation and higher resource use efficiency.

- Reduction of greenhouse gas (methane) Emissions.

- Improvement of air quality.

- Enhance the use of green energy from biogas based electricity generation.

\section{Current Difficulties}

Solid waste management is the worldwide concern wherein 2016, the estimation of the total amount of municipal solid waste generated globally reached 2.02 billion tonnes and representing a 7\% annual increase since 2003 (Key Note Publications Ltd., 2007). Various alternative technologies have been in place for handling municipal solid waste such as anaerobic digestion to produce biogas for energy generation. The compost as a soil conditioner from this technology would serve a sustainable option, as it would reduce the amount of biodegradable fraction of municipal solid waste destined to the dumpsite in Kigali City.

As also the benefit from the presented technology, it would reduce the pollution burden of underground water as well as surface water from the leachate generated by decaying/rotting organic waste. The added benefit of recovering energy and compost as a soil conditioner enhances the attractiveness of the anaerobic digestion technology. Although the electricity as an essential driver of modern technology and social-economic, where it may be used for cooking, lighting, phones charging and industrial processing. It currently represents $4 \%$ of primary energy consumed in Rwanda However, the action to grow exponentially over coming years has been planned and the population access to the electricity is $19 \%$ to increase the accessibility up to $70 \%$ (Ministry of Infrastructure, 2014).

The accessibility to electricity in Rwanda remains low and particularly in rural areas. Even if the plan is implemented, by $2020,40 \%$ of the population will stay without electricity. However, the rate of electricity increased from $6 \%$ in 2008 to $35.3 \%$ in May 2017. Additional effort is needed to supply electricity to those people who will be Keeping away from domestic network (Dennis Matanda \& Rwandan Ministry of Infrastructure, 2017). 
According to the EWSA report: "Although the electricity access level in Rwanda is still low compared with Africa's and sub-Saharan Africa's average access rates of $40 \%$ and $31 \%$ respectively, the country's electricity access rate has more than tripled from $5 \%$ in 2005 to the current access rate of $18 \%$. To achieve the above access rate target above by 2018, Rwanda will explore both on-grid and off-grid solutions ranging from solar home systems to small off-grid hydro installations." (Ministry of Infrastructure-the Republic of Rwanda, 2015).

However, the development of power projects in recent years has increased power supply from $2 \%$ in 2000 to $16 \%$ in January 2013. The continued expansion of the grid by 2018 was expected to come from hydropower (168.68 MW); solar (20 MW), methane (253.6 MW); and peat (210 MW). (Ministry of Infrastructure-the Republic of Rwanda, 2015).

This means that in Rwanda there is a gap in electrical energy, the problem of energy aggravated by lack of the ability of implementation of new technology. Nonetheless, the management of biodegradable fraction of solids waste generated from Kigali city even somewhere else in Rwanda will drop the electricity energy gap present through the production of biogas and biogas engines for the electricity production.

This paper evaluates the potential technology of anaerobic digestion to reduce the quantity of solid waste destined to the dumpsite in Kigali and evaluate the viability of using the biodegradable waste meant to the land. The biogas produced is undertaken to analyze the cost and benefit of the anaerobic digestion technology.

\section{Relationship of Methane Generation and Organic Matter}

\subsection{Step 1: Calculation of COD Equivalent of $\mathrm{CH}_{4}$}

The technology requires the use of chemical reaction to calculate unites mass for each constituent in methane combustion (Equation (1)).

$$
\mathrm{CH}_{4}+2 \mathrm{O}_{2} \rightarrow \mathrm{CO}_{2}+2 \mathrm{H}_{2} \mathrm{O}
$$

The unit masses may balance on both sides of the equation by putting a number to the equation: $16 \mathrm{~g}+2 \times 32 \mathrm{~g}=44 \mathrm{~g}+2 \times 18 \mathrm{~g}$. The mass of one mole of methane is $16 \mathrm{~g}$, the 2 moles of $\mathrm{O}_{2}$ has a mass of $64 \mathrm{~g}$, so each gram of methane represents 4 grams of Oxygen demand (OD) and the Chemical Oxygen demand (COD) is generally used to determine $\mathrm{OD}$ for anaerobic digestion.

$$
\begin{gathered}
\Rightarrow 16 \mathrm{~g} \mathrm{CH}_{4} \sim 64 \mathrm{~g} \mathrm{O}_{2}(\mathrm{COD}) \rightarrow \mathrm{CO}_{2}+2 \mathrm{H}_{2} \mathrm{O} \\
\Rightarrow 1 \mathrm{~g} \mathrm{CH}_{4}=\frac{64}{16}=4 \mathrm{~g} \mathrm{COD}
\end{gathered}
$$

\subsection{Step 2: Conversion of $\mathrm{CH}_{4}$ Mass to an Equivalent Volume}

Based on gas law, 1 mole of any gas at STP (Standard Temperature and Pressure) occupies a volume of $22.4 \mathrm{~L}$.

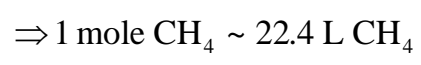




$$
\begin{gathered}
\Rightarrow 16 \mathrm{~g} \mathrm{CH}_{4} \sim 22.4 \mathrm{~L} \mathrm{CH}_{4} \\
\Rightarrow 1 \mathrm{~g} \mathrm{CH}_{4} \sim 22.4 / 16=1.4 \mathrm{~L} \mathrm{CH}_{4}
\end{gathered}
$$

\subsection{Step 3: $\mathrm{CH}_{4}$ Generation Rate per Unit of COD Removed}

From Equation (1) and Equation (2), we have,

$$
\begin{gathered}
\Rightarrow 1 \mathrm{~g} \mathrm{CH}_{4} \sim 4 \mathrm{~g} \mathrm{COD} \sim 1.4 \mathrm{~L} \mathrm{CH}_{4} \\
\Rightarrow 4 \mathrm{~g} \mathrm{COD} \sim 1.4 \mathrm{~L} \mathrm{CH}_{4} \\
\Rightarrow 1 \mathrm{~g} \mathrm{COD} \sim 1.4 / 4=0.35 \mathrm{~L} \mathrm{CH}_{4}
\end{gathered}
$$

Or

$$
\Rightarrow 1 \mathrm{~kg} \mathrm{COD} \sim 0.35 \mathrm{~m}^{3} \mathrm{CH}_{4}
$$

Equation (3), predict the volume of Methane released per mass of OD removed and gives an estimate of the amount of organic matter that will be converted to $\mathrm{CH}_{4}$ during the digestion and the complete anaerobic degradation of 1 $\mathrm{kg}$ COD produces $0.35 \mathrm{~m}^{3} \mathrm{CH}_{4}$ at STP.

\section{Existing Digester Designs}

The anaerobic digesters can be broadly classified into three categories namely low solids content digesters, high solids content digesters and the two-phase anaerobic digesters. Each category is further classified based on the temperature required, type of mixing, and the identification of mode of feeding. High solids digesters achieve high loading rates and minimize costs of de-watering the digested slurry as well as water requirements. However, it poses a great challenge during starting, feeding, and mixing. Low solids anaerobic digester requires less power for mixing but poses problems of bulkiness due to the high amount of water content (high level of moistures) as well as increased costs of de-watering the digested slurry. Also, some researches have shown that the formation of a hard scum layer on top of the digester slurry is a practical problem often encountered (Deboosere, Meenen, Boetin, Sudrajat, \& Verstroete, 1988).

The two-phase digester attempts to reduce the anaerobic digestion time by allowing the solubilization and acidification bacteria to operate in the 1st phase and the sensitive groups of bacteria. The acetogenins and the methanogens operate in the 2 nd phase and the major advantages of the multiphase digesters include improved stability, the concentration of the slow-growing acetogenins and methanogens for the production of biogas whose methane content is higher since most of the carbon dioxide has been released in 1st phase (Chynoweth, 1996). However, it has one disadvantage, which is related to the complexity of the design and the operation. Figure 1 shows the biogas production process stage by stage with anaerobic digestion method.

\section{Materials and Method}

\subsection{Material Requirement}

The balance was used for weighing the garbage generated from each model 


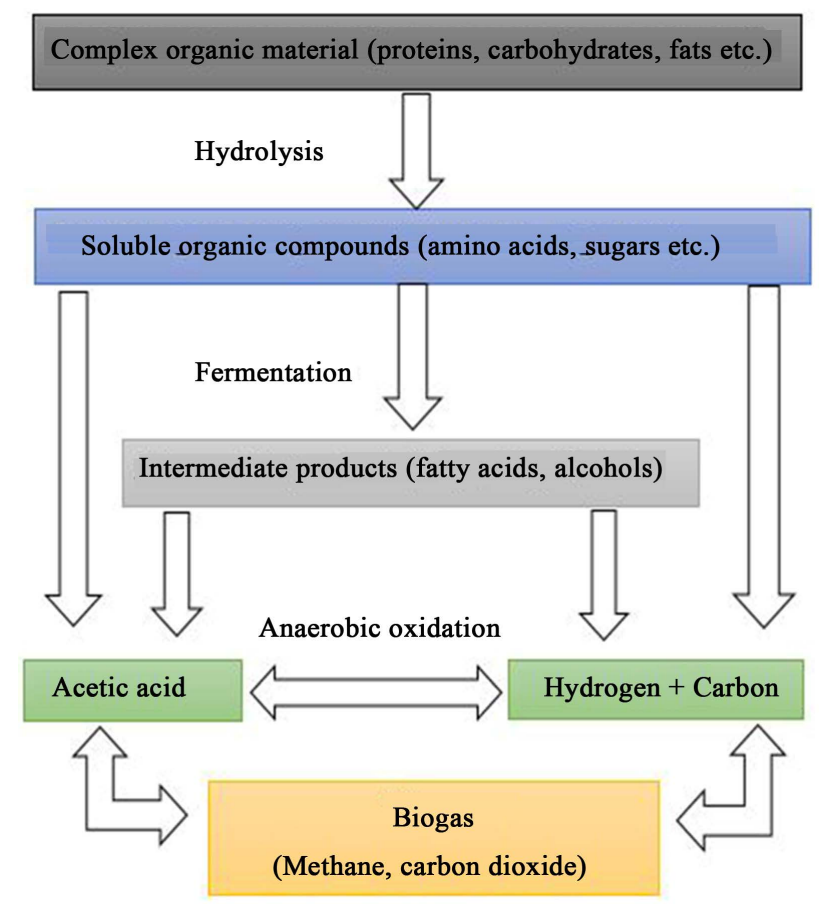

Figure 1. Biogas process is divided into multiple stages in the digestion process.

houses in Kigali city. Scale having the accuracy up to $100 \mathrm{~g}$ was used so that the reliable weight of the lightest refuse could be measured. The total mass of garbage from each model house was weighted before sorting. The two sacks were used for sorting the organic waste to inorganic waste and dispose of the organic waste in the green sac and the inorganic waste in a blue sac to further identify the other types of municipal waste. The same procedure was adopted over the weekly study period. The rubber gloves were used for hands protection and dust masks for respiratory protection. The results were recorded in a tabular format.

\subsection{Physical-Chemical and Biological Characteristics}

Physical and chemical characteristics of feedstock are identified by the determination of dry matter content (DM), volatile solids content (VS), chemical oxygen demand (COD) and $\mathrm{BOD}^{5}$ where samples used for determination of COD and $B O D 5^{20}$, is first subjected to particle size reduction by chopping them into small pieces with a knife. Further particle size reduction and solubilization affected by the use of a domestic kitchen knife and de-ionized water.

\subsection{Dry Matter Content (DM) and Volatile Solids (VS)}

The dry matter content of a feedstock is determined by drying a pre-weighed sample of raw waste at $105^{\circ} \mathrm{C}$ until a constant weight is achieved. Effectively it is the residue left after evaporating the water from a sample volume and drying the residue in a kiln until a constant weight is obtained. The weight of the residue over the weight of the wet sample is expressed in a referred percentage to the Dry Matter content (DM). The volatile solids content of a sample is defined as 
the difference between the ash content and the Dry Matter content divided by the total solids content and it is all expressed in percentage. Also, the ash content is defined as the residue left after incinerating the dry sample at $450^{\circ} \mathrm{C}-600^{\circ} \mathrm{C}$.

Both DM and VS determination is carried out according to standard methods for the examination of water and wastewater as described by (Greenberg et al., 1992).

\subsection{Chemical Oxygen Demand (COD) of Feedstock}

A $100 \mathrm{~g}$ of the sample from each digester is used for the test to create the suspension of organic matter of solid organic material, the sample was chopped into very small pieces. The samples are diluted to the required concentration measured by a pipette of $15 \mathrm{~mL}$ plastic vials. Additionally, $10 \mathrm{~mL}$ glass vials and caps are required to perform the COD test on the diluted sample. The followings chemicals are added to the $20 \mathrm{ml}$ of diluted organic waste to test the COD:

- $30 \mathrm{~mL}$ concentration of the sulphuric acid solution.

- $10 \mathrm{ml}$ of potassium dichromate solution.

- $40 \mathrm{~g} / \mathrm{L}$ mercuric Sulfate (Punch).

Further to these chemicals, a vortex reactor of $150^{\circ} \mathrm{C}$ and spectrophotometer were required to test for COD. Finally, the Microsoft Excel software is used to organize the data and to calculate the COD in $\mathrm{kg} / \mathrm{kg}$ dry waste from the absorbance values provided by the spectrophotometer.

The spectrophotometer produces measures of absorbance which are converted into grams per litre of COD using a calibration curve. This value can be converted into COD in $\mathrm{kg} / \mathrm{kg}$ dry waste by multiplying the COD of the sample in $\mathrm{kg}$ per Liter by the known sample concentration in kg per Liter.

$$
\frac{\mathrm{kg} \text { COD }}{\mathrm{kg} \text { Dry waste }}=\frac{\mathrm{kg} \mathrm{COD}}{\mathrm{L}} * \frac{\mathrm{L}}{\mathrm{kg} \text { Dry waste }}
$$

COD determination is performed according to standard methods for the examination of water and wastewater as described by (Greenberg et al., 1992).

\subsection{Biochemical Oxygen Demand (BOD) of Feedstock}

An amount of sample from different digesters with chopped particles into small pieces is used to dilute water which is aerated before adding the nutrient solution. A various chemical composition such as Manganous Sulphate solution $\left(\mathrm{MnSO}_{4} \cdot 4 \mathrm{H}_{2} \mathrm{O}\right)$, Winkler $\left(\mathrm{MnSO}_{4}\right)$, Sodium Thiosulphate $\left(\mathrm{Na}_{2} \mathrm{~S}_{2} \mathrm{O}_{3} \cdot 5 \mathrm{H}_{2} \mathrm{O}\right)$, sulphuric acid, and starch indicator was prepared. The $125 \mathrm{ml}$ BOD bottles, an assorted glass with $200 \mathrm{~mL}$ and $50 \mathrm{ml}$ glass cylinder is used to dilute the sample with $1 \mathrm{mg}$ of the sample at each litre of diluted water. The $10 \mathrm{~mL}$ of Manganous Sulfate, $10 \mathrm{~mL}$ of Winkle and $10 \mathrm{~mL}$ of Sulphilic acid is added to the sample contained in the bottle for the sample of $50 \mathrm{~mL}$ to be titrated with Thiosulphate Solution after adding the indicator.

The incubator is calibrated at $20^{\circ} \mathrm{C} \pm 1^{\circ} \mathrm{C}$ after measuring initial $\mathrm{DO}$ concen- 
tration (D1) for the sealed BOD sample to be placed in the incubator air and the sample is incubated at $20^{\circ} \mathrm{C} \pm 1{ }^{\circ} \mathrm{C}$ for 5 days. At the end of 5 days \pm 4 hours, the final DO concentration (D2) is measured. Finally, BOD5 is computed as (DO0 days - DO5 days).

The methodology used for this test was titration and the BOD determination is performed according to Five-day biochemical oxygen demand as described by G.C. Delzer and S.W. McKenzie, (November 2003). The physical and chemical characteristics of Lab-scale Digester Slurry is determined for the dry matter content (DM), volatile solids content (VS), chemical oxygen demand (COD), BOD5, Samples is used for determination of COD and BOD520. It is first subjected to particle size reduction by chopping them into small pieces with a knife. Further particle size reduction and solubilization were affected by the use of a domestic kitchen knife and de-ionized water.

\subsection{Sizing Anaerobic Digester for Municipal Solids Waste in Kigali City}

The specification of the larger scale of high solids anaerobic digester is based on the values obtained from the waste quantification and characterization exercises. The appropriate input parameters like the feedstock volumetric flow rate are ascertained that aided the bioreactor design using the following formulae.

$V_{r}$ : volume of the reactor.

$V_{g}$ : Volume of gas the holder.

$V_{\dot{d}}$ Volume of the bio-digester.

$Q$. Volumetric rate.

HRT: Hydraulic Retention Time of the feedstock in days.

OLR: Organic Loading Rate.

Assume the volume of the gasholder to be the half of the reactor $\Rightarrow V_{g}=\frac{V_{r}}{2}$;

$V_{d}=V_{r}+V_{r} / 2=3 V_{r} / 2$

Digester model selection and dimensioning

Basing on the standard sizes of the selected digester model with geometric formulae the appropriate dimension of the digester was determined.

- The reactor with a cylindrical tank of the volume $\left(V_{r}\right)$

As

$$
V_{r}=\frac{\pi D^{2} H}{4}
$$

where $D$ is the diameter of the tank and

$H$ is the height of the tank

Assume $D=H$ Hence

$$
V_{r}=\frac{\pi D^{3}}{4}
$$

Hence the diameter $D$ can be given as

$$
D=\sqrt[3]{\frac{4 V_{r}}{\pi}}
$$


Taking the gasholder/digester radial clearance to be $300 \mathrm{~mm}$, gives a diameter (d) of the gas holder as:

$$
d=\left(\sqrt[3]{\frac{4 V_{r}}{\pi}}\right)-0.6
$$

\section{Results and Discussion}

\subsection{Chemical Characteristics of Organic Fraction of Municipal Solid Waste}

From the data on MSW characterization over 24 weeks, the mean values for the physical-chemical characteristics of DM, VS, COD, and BOD obtained is 22.4, $910.228 \mathrm{~g} \mathrm{VS} / \mathrm{kg} \mathrm{DM}, 1328.262 \mathrm{~g}$ COD/kg DM and $597.714 \mathrm{~g}$ BOD $/ \mathrm{kg}$ respectively see Table 1 .

A dry matter content of $22.4 \%$ agrees with other figures obtained by researchers working in this field. Brummeler et al. (1992) obtained a value of $36 \%$ for the source-separated organic fraction of MSW consisting of mainly vegetable, fruit, and yard trimmings. Wellinger, Baserga, \& Egger (1992) have reported that dry matter content of source-separated MSW with composition as described ranges from $18 \%$ to $30 \%$. The dry matter content may be taken as an estimate of the chemical oxygen demand since a kilogram of dry MSW contains about $1.305 \mathrm{~kg}$ COD. The volatile solids content was found to be lower than the COD. Possibly this was because of the loss of alcohols and acetic acids which may have volatilized during the heating process.

The value for BOD5 was found to be $597.714 \mathrm{~g} \mathrm{BOD} / \mathrm{kg}$ for Municipal waste. From (Hur, Lee, Lee, \& Park, 2010), BOD/COD ratios ranged from 0.26 to 0.77 for the non-urban areas whereas the urban areas exhibited much smaller range from 0.32 to 0.58 , therefore, a value of 0.458 rations for $\mathrm{BOD} / \mathrm{COD}$ ratio is acceptable.

\subsection{Chemical Characteristics of Digester Slurry}

From the data on Anaerobic Digester Slurry characterization over 24 weeks, the values for the physical-chemical characteristics of DM, VS, COD, and BOD obtained were 10.5, $630.177 \mathrm{gVS} / \mathrm{kg} \mathrm{DM}, 754.293 \mathrm{gCOD} / \mathrm{kg} \mathrm{DM}$ and $255.856 \mathrm{~g}$ $\mathrm{BOD} / \mathrm{kg}$ respectively, see Table 2 . The data shows that the total solids was about $10.5 \%$ and therefore implying that anaerobic digestion of MSW at low solids was carried at $10.5 \%$ TS. Phale (2005) have given the range at which low solids anaerobic digestion can take place as $8 \% \mathrm{TS}$ to $12 \% \mathrm{TS}$. The volatile solids, Biological oxygen demand, and the chemical oxygen demand indicate the active biomass in the sludge.

Table 1. Summary of the MSW characteristics over 24 weeks.

\begin{tabular}{cccc}
\hline Percentage Matter & Dry Volatile solids & Chemical Oxygen demand & Biochemical Oxygen demand \\
\hline$(\% \mathrm{DM})$ & $(\mathrm{gVS} / \mathrm{kg} \mathrm{DM})$ & $(\mathrm{gCOD} / \mathrm{kg} \mathrm{DM})$ & $(\mathrm{gBOD} / \mathrm{kg} \mathrm{DM})$ \\
22.4 & 910.228 & 1304.576 & 597.714 \\
\hline
\end{tabular}


Table 2. Summary of the anaerobic digester slurry characteristics.

\begin{tabular}{ccccc}
\hline & $\begin{array}{c}\text { Percentage } \\
\text { Matter (\% DM) }\end{array}$ & $\begin{array}{c}\text { Dry Volatile solids } \\
(\mathrm{gVS} / \mathrm{Kg} \mathrm{DM})\end{array}$ & $\begin{array}{c}\text { Chemical oxygen demand } \\
(\mathrm{gCOD} / \mathrm{Kg} \mathrm{DM})\end{array}$ & $\begin{array}{c}\text { Biochemical Oxygen } \\
\text { demand (gBOD/Kg DM) }\end{array}$ \\
\hline D1 & 10.5 & 647.72 & 890.4 & 303.959 \\
D2 & 12 & 605.334 & 700.48 & 246.893 \\
D3 & 10 & 637.478 & 672 & 216.716 \\
mean & 10.5 & 630.177 & 754.293 & 255.856 \\
\hline
\end{tabular}

\subsection{Design Consideration}

From the survey done in Kigali city, it was seen that the daily municipal solid waste generated in Kigali city is about $686,000 \mathrm{~kg}$ out of which, the organic waste is with a high rate and the organic waste are the most generated at a rate of $73 \%$ corresponds to $500,000 \mathrm{~kg}$. The dry matter content for this fraction of MSW is about $22.4 \%$ corresponds $112,500 \mathrm{~kg}$. The fraction of organic matter can be gathered and used as raw material for industrial-size anaerobic digestion for the production of biogas, which will generate green electricity and compost as the end products and consequently, reduce the amounts of MSW destined for the dumpsite.

The optimization of anaerobic digestion of MSW and other substrates is dependent upon understanding the microbial mechanisms involved and the application of this knowledge for improved design, operation performance evaluation, and control.

Anaerobic digestion of MSW has been investigated in the laboratory. The results obtained as well as those calculated based on the data are listed in Table 1.

\subsubsection{Methane Generated in Terms of Dry Matter}

From studies done in the laboratory, one $\mathrm{kg}$ of dry matter produce $1.305 \mathrm{~kg}$ of COD at normal conditions (see Table 3); $273.15 \mathrm{~K}\left(0^{\circ}\right)$ and 1.013 bars (atmospheric pressure), the methane will be produced from $1 \mathrm{~g}$ of dry matter equal to $0.457 \mathrm{~L} \mathrm{CH}_{4}$; from the Equation (3) in Section $3\left(1 \mathrm{~kg} \mathrm{COD} 0.35 \mathrm{~m}^{3} \mathrm{CH}_{4}\right.$ and $\left(1 \mathrm{~kg} \mathrm{DM}=457 \mathrm{~L} \mathrm{CH}_{4}\right)$. From the laboratory test, it was seen that the dry matter content is $22.4 \%$ of Municipal waste. Further Kigali city will produce 51,384,375 $\mathrm{L}$ of methane as it generates $112,500 \mathrm{~kg}$ of dry matter.

\subsubsection{The Energy Content of Biogas}

A typical normal cubic meter of methane [Volume at normal conditions, $273.15 \mathrm{~K}(0 \mathrm{o})$ and 1.013 bars (atmospheric pressure)]. has a calorific value of around $10 \mathrm{kWh}$, while carbon dioxide has zero. The energy content of biogas is therefore directly related to the methane concentration. In other words, assuming a biogas composition with $50 \%$ methane, the energy content would, in this case, be around $5.0 \mathrm{kWh}$ per normal cub meter. Therefore, normal cubic meter cube for natural gas is assumed $11 \mathrm{kWh}$ energy content (Sector, 2012). The methane produced from the MSW generated from Kigali city will contain $565,228 \mathrm{KWh}$. 
Table 3. Feedstock characteristics.

\begin{tabular}{cc}
\hline Parameters & Values \\
\hline The average daily generation rate & $500,000 \mathrm{~kg}$ \\
Total solids & $22.4 \%$ \\
Moisture content & $77.6 \%$ \\
Volatile solids (VS) (\%TS) & $91.02 \%$ \\
Fixed Solids (FS) (\%TS) & $8.98 \%$ \\
Density & $775.0 \mathrm{~kg} / \mathrm{m}^{3}$ (Kigozi, Aboyade, \& Muzenda, 2014) \\
\hline
\end{tabular}

\subsubsection{Electricity Generation}

Biogas can be used in many ways includes Heat. The gas is combusted in a boiler. The heat generated warms up water which can be used to heat the digester and nearby buildings or be exchanged on a local district heating network. A gas boiler works like a boiler for solid and liquid fuels, but with the difference that the boiler is specially modified to combust gas. Moreover, biogas can be used as a fuel in stationary engines, typically Otto or diesel engines, or gas turbine. Electricity is produced from biogas through combustion in a gas engine or a turbine. Both Otto and diesel engines are used. About a third of the energy in the fuel is used to produce electricity and two-thirds becomes heat. About $30 \%-40 \%$ of the energy in the fuel is used to produce electricity while the remaining energy becomes heat. Assuming the energy in the fuel produce the electricity is $32 \%$ the electricity will be produced in Kigali city will be $180,873 \mathrm{KWh}$ per day.

\subsubsection{Sizing Anaerobic Digester for Municipal Solids Waste in Kigali City Plant size Feedstock characteristics}

Table 3 shows the characteristics of feedstock. Generally, the OMSW characteristics obtained were in agreement with most of the reviewed literature (Kigozi et al., 2014) indicated that typical OMSW has TS and VS ranges of $20 \%-30 \%$ and $90 \%-95 \%$ respectively.

\section{1) Bioreactor size}

$$
Q=500000 \mathrm{~kg} / 775.0 \mathrm{~kg} / \mathrm{m}^{3}=645 \mathrm{~m}^{3} / \text { day }
$$

To achieve substrate fluidity, the feedstock is mixed with water at a ratio of 1:1. Hence, an additional $645 \mathrm{~m}^{3}$ of water is to be added giving a total feedstock flow rate of the approximately $1290-\mathrm{m}^{3}$ per day.

From Literature HRT is in the range of $21-30$, take the maximum HRT 30 days

$$
V_{r}=1291.606 \mathrm{~m}^{3} / \text { day } \times 30 \text { days }=38710 \mathrm{~m}^{3}
$$

OLR for OMSW range between $5-10 \mathrm{~kg} \mathrm{VS} / \mathrm{m}^{3}$

$$
\text { OLR }=(Q \times S) / V_{r}
$$

$S=$ Concentration of Volatile Solids in the input $\left(\mathrm{kg} / \mathrm{m}^{3}\right)$

$$
S=\mathrm{TS} \times \mathrm{VS} \times \text { Density }
$$




$$
\begin{gathered}
S=0.224 \times 0.9102 \times 775=158 \mathrm{~kg} / \mathrm{m}^{3} \\
\text { OLR }=1291.606 \times 158.0107 / 38748.193=5.267 \mathrm{~kg} \mathrm{VS} / \mathrm{m}^{3}
\end{gathered}
$$

It is seen that Organic loading rate is within the range $5-10$ means $38,710 \mathrm{~m}^{3}$ reactor size is ok

\section{2) Gasholder size}

$$
\begin{gathered}
V_{g}=V_{r} / 2=38710 \mathrm{~m}^{3} / 2=19355 \mathrm{~m}^{3} \\
V_{d}=V_{g}+V_{r}=58065 \mathrm{~m}^{3} \\
D=\sqrt[3]{\frac{4 \times 38710}{\pi}}=36.67 \mathrm{~m} \\
H=D \\
d=D-0.6=36.07 \mathrm{~m} \\
h=\frac{4 V_{g}}{\pi d^{2}}=18.65 \mathrm{~m}^{?}
\end{gathered}
$$

Based on calculations, Table 4 shows the dimensions of bio digesters of MSW in Kigali city, the volume of digester (total volume), bio reactor volume, gas holder volume, total height of digester, the height of the gas holder, outer diameter and the inner diameter found to be $38,710 \mathrm{~m}^{3}, 19,355 \mathrm{~m}^{3}, 58,065 \mathrm{~m}^{3}$, $36.67 \mathrm{~m}, 18.65 \mathrm{~m}, 36.67 \mathrm{~m}, 36.07 \mathrm{~m}$ respectively.

\subsubsection{Digester Model Selection and Dimension}

The selected digester is commercial Biogas digester with a cylindrical design and vertical classification design. The digester consists of vertical concrete or steel digesters with rotating propellers or immersion pumps for widespread homogenization. This was chosen because is simpler and cheaper to operate, but the feedstock may not reside in the digester for the optimum period. The digester will be built underground.

\subsection{Costs and Benefits Analysis Costs}

\subsubsection{Investment Cost}

The investments costs are undoubtedly the most significant in the process of energy recovery from MSW by use of anaerobic digestion. It is related to the quantity and description of materials required for the construction of complete high solids anaerobic digester.

The quantities of some major construction materials for digester are estimated in Table 5 as rebar, Cement, sand, and Gravel with 177 Tons, 1573.531 Tons, $6970.63 \mathrm{~m}^{3}, 3933.827 \mathrm{~m}^{3}$ respectively.

Table 4. Bio digesters dimensions.

\begin{tabular}{ccccccc}
\hline$V_{r}\left(\mathrm{~m}^{3}\right)$ & $V_{g}\left(\mathrm{~m}^{3}\right)$ & $V_{d}\left(\mathrm{~m}^{3}\right)$ & $H(\mathrm{~m})$ & $h(\mathrm{~m})$ & $D(\mathrm{~m})$ & $d(\mathrm{~m})$ \\
\hline 38,710 & 19,355 & 58,065 & 36.67 & 18.65 & 36.67 & 36.07 \\
\hline
\end{tabular}


Table 5. The quantity and description of materials.

\begin{tabular}{ccc}
\hline Materials & Quantity & Unity \\
\hline Rebar & 177 & Ton \\
Cement & 1573.531 & Ton \\
Sand & 6970.63 & $\mathrm{~m}^{3}$ \\
Gravels & 3933.827 & $\mathrm{~m}^{3}$ \\
\hline
\end{tabular}

In construction, there are different steps and works undertaken for accomplishing the project. The required works and steps in the construction of the commercial anaerobic digestion plan are the following:

\section{1) Facility Layout}

Facility layouts it consists of selecting the layout of construction as singlestage biogas facility with a longer track record and has lower capital costs and technical problems and two-stage biogas facility digestion in two different tanks to optimize the operating conditions.

\section{2) Dimension Making}

Dimension marking is considered as preparation for excavation and construction. A width of $3 \mathrm{~m}$ around the digester should be considered. Workers to achieve the construction works around the tank base to prepare the structure of the concrete base, use this area.

\section{3) Excavation Works}

The depth of digging depends on the specifications of the soil. The inclination of the sides should is $30 \mathrm{~cm}$ for each meter depth for the cohesive soil, $60 \mathrm{~cm}$ to one meter for the light soil, and $90 \mathrm{~cm}$ for the sandy soil.

Preparation of the digester's bottom

The bottom is constructed using the water: cement ratio $\left(0.53 \mathrm{~L} \cdot \mathrm{kg}^{-1}\right)$, cement: sand: gravel mass ratios (1:2.2:3.7) and pre-selected type of iron rods with them as either $6 \emptyset 6 \mathrm{~m}^{-1}$ or $6 \varnothing 8 \mathrm{~m}^{-1}$. The thickness of the concrete base ranges between $10-25 \mathrm{~cm}$ depending on the soil's specifications and the groundwater level.

\section{4) Building the Digester}

The commercial biogas plants are huge as its diameter reach $36.68 \mathrm{~m}$; therefore, the concrete structure should be reinforced. Hence, the iron rods are used to build 2 iron grids to reinforce the digester wall starting from the digester bottom plate. The standard length of iron rods is $12 \mathrm{~m}$.

\section{5) Integrating the Heating Tubes}

The heating tubes should be integrated into the wall structure with structuring the iron grids which will be encased by wood panels or pre-constructed metal sheets, and before pouring the concrete, the heating tubes are made of polyvinyl chloride (PVC), inside these tubes hot water flows to heat the digester. The water temperature is either $35^{\circ} \mathrm{C}$ or $55^{\circ} \mathrm{C}$ depending on the used bacteria as either mesophilic of thermophilic bacteria, respectively.

6) Building the Gas Holder

A wood or steel structure in the form of umbrella is built, and then a mesh 
network is relayed on the umbrella structure. The air-supported double-membrane cover, which includes the gas holder, is mounted over the structure. The flexible membrane of the gas collector.

\subsubsection{Technology Installation}

The technology that should be installed includes the filling indicator, tubes, measuring devices and meters, electricity network, fibre cables, mixers etc. Afterwards, the gas collector should be installed as well as the excess and lowpressure safeguard and the air support fan.

\subsubsection{Installing the Insulation}

This is the process of lining the digester by mortar or using sheets of foam. This is one of the most important construction steps and should be carefully and accurately achieved. In the case of lining, the process is performed using mortar containing $1 \%$ silica. After the completion of the lining, the digester is painted using the petroleum Albumen.

The description and quantities of materials and their prices which are required for construction of the digester are estimated from Table 6. The below price is the total estimated price which is $\$ 110,311,034.5 \approx \mathrm{Ksh} 11,240,597,178 \approx$ $89,924,777,426$ rwf.

At $50 \%$ labour cost, the overall cost of a $58,065 \mathrm{~m}^{3}$ the investment costs for the high solids anaerobic digester is estimated at $89,924,777,426 \mathrm{rwf}$ for a payback period of 10 years at a compound interest of $15 \%$ p.a., the annual payment amount to $22,481,194,357$ Rwf.

Table 6. Inventory of materials and their price estimates.

\begin{tabular}{|c|c|c|c|c|}
\hline Materials & Quantity & Unity & Unit price $\$$ & Total price \\
\hline Rebar & 177 & Ton & 365 & 64,605 \\
\hline Sand & 6970.63 & $\mathrm{~m}^{3}$ & 0.8 & 5577 \\
\hline Gravels & 3933.827 & $\mathrm{~m}^{2}$ & 20 & 78,677 \\
\hline Cement & 1573.531 & Ton & 4250 & $7,474,272$ \\
\hline Bulldozer & 6970.63 & $\mathrm{~m}^{3}$ & 0.8 & 5577 \\
\hline $\begin{array}{l}\text { Pre-Constructed metal sheets: to protect } \\
\text { the internal face of the wall } \\
\text { against corrosion; } 1.3 \text { of } \mathrm{Vd} \text { : }\end{array}$ & 1408.2 & $\mathrm{~m}^{2}$ & 150 & 71,075 \\
\hline Cement: Sand & 01:04 & $\mathrm{kg}$ & done & \\
\hline Heating tubes: Hot tube heater & $232,489.16$ & pce & 60 & $13,949,349$ \\
\hline $\begin{array}{l}\text { Miscellaneous: The filling indicator, tubes, } \\
\text { measuring devices and meters electricity } \\
\text { network, fiber cables, welding rods, mixing... }\end{array}$ & N/A & N/A & N/A & 5000 \\
\hline Biogas electricity generator Samsung $10-1000$ & 3 & pce & 10,000 & 30,000 \\
\hline Sheets of foam for the insulation & 4224.6 & $\mathrm{~m}^{2}$ & 3.6 & 5109 \\
\hline $\begin{array}{l}\text { Painting the insulation } \\
\text { using the Petroleum Albumen }\end{array}$ & 4224.6 & $\mathrm{~m}^{2}$ & $59 /$ barrel & 210 \\
\hline Total \$ & & & & $\$ 110,316,035$ \\
\hline
\end{tabular}




\subsubsection{Maintenance and Operation Costs}

A biogas plant with an annual operating capacity of 500.000 tons a year requires 5 - 9 hours' work daily to keep the amount of work gone to a minimum with a particularly recommended use of effective measurement of control technology. For safe exchange of data, it is also possible for someone who is not on-site to monitor and control the unit, i.e. the unit can be remotely controlled. For example, the agitators can be switched on and off, and all the solid supply equipment can be monitored. Information about malfunctions can be registered on computer service or the operator's mobile phone, these guarantees a short reaction time when anything unexpected happens.

The plant produces $180,873 \mathrm{kWh}$ of electricity per day with 500.000 tons of biomass. It will be needed minimum maintenance costs to run several years for the optimal gas processing engines.

Up to $30 \%$ of the waste heats from the water cooling the engine is used in the heat exchanger and the fermenter so that no additional heat is required, the remaining heat can also be used profitably to heat industrial plants and houses. The electric power generated by the Combined Heat and Power Plant (CHP) is converted to high voltage and then the electricity can be fed into the grid who meets the annual requirement of around 235,560 households.

\subsection{Benefits}

\section{Benefits from the Biogas Energy Generated in Kigali City}

The cost of electricity supply from hydropower will be reduced while using the electricity produced from gas methane. The electricity produced from the Biomass is less costly than that produced by hydropower. These can be shown by calculations, the income in Ksh as electricity cost is equivalent to $20 \mathrm{Ksh} / \mathrm{KWh}$ it will be 3,617,460 Ksh equivalent to 28,939,680 Rwf per hour and Annual savings from the municipal solids waste of Kigali can be $2.54206 \mathrm{E}+11 \mathrm{Rwf}$.

With the study of Green Economy Sectorial on the energy -RWANDA, biomass contributes 86 per cent to the primary energy supply in Rwanda. Electricity access remains very low and, in 2010, electricity per capita use was $26.5 \mathrm{kWh}$ per person. From the municipal solids waste the population of Kigali will benefit the electricity from biogas and the rate of the population access the electricity will be increased, as the electricity will be increased about $18 \% \mathrm{kWh} /$ person.

Currently, only 6 per cent of the households having access to energy this rate is very low as it can be raised by producing the electricity from municipal solids waste. The country has currently $243,000 \mathrm{KWh}$ as well as the organic solid waste generated from Kigali city may produce $180,873 \mathrm{KWh}$ which is $56 \%$ of the daily demand in Rwanda. The percentage of electricity per household will be increased.

Kigali alone accounts for nearly 2 thirds of total electricity consumption in the country. Based on annual electricity energy requirement for Kigali city per people, the benefits of using biogas can be calculated as the increase in electrical energy gained from biogas. 


\section{Conclusion}

The research was conducted to evaluate the anaerobic digestion feasibility in producing the biogas from municipal organic waste in Kigali city. Discussions form the preceding result highlights the possibilities of reusing biowaste in biogas production for energy recovery as a means of promoting green energy from waste. From the survey done in Kigali city, it was shown that organic waste is more generated. It yields a $73 \%$ rate with $(500,000 \mathrm{~kg})$ of total municipal waste. This implies that while managing the organic waste by producing the biogas, the population of Kigali city will benefit it. While it is relatively possible to manage solid waste in Kigali city, the management of organic solid waste requires advanced planning to facilitate the operation of biogas production. The results indicated that the organic waste in Kigali city can reduce $457 \mathrm{~L} / \mathrm{kg}$ DM of methane. The value $457 \mathrm{~L} / \mathrm{kg}$ DM was considered for calculating the methane and electricity generation potential. The overall assessed value of methane was 51,384,375 L, and the electricity from derived methane was $180,873 \mathrm{KWh}$ which is $56 \%$ of the daily demand in Kigali city. The quantity of municipal waste generated in Kigali city was used for designing the biodigester required. The volume of the biodigester was found to be $58,065 \mathrm{~m}^{3}$. Based on the energy recovered, a cost-benefit was done and revealed that Kigali city will benefit this project as the population accessing the electricity will be increasing but now it is still low.

\section{Acknowledgements}

Authors would like to thank Mr Kipyego, Samoei, Mr Mwachoni, for their help in conducting laboratory experiment and tests. Special thanks go to COPED Company and City of Kigali for their contribution with data collection. The University of Rwanda and Intra ICP ARISE scholarship thanks by supporting us financially.

School of Biology authority (University of Nairobi) thanks for permitting us to carry out the tests in their school laboratories.

Professor Agnes Muthumbi thanks for your constructive ideas and their contribution in writing and editing of this paper.

\section{Conflicts of Interest}

The authors declare no conflicts of interest regarding the publication of this paper.

\section{References}

Adhikari, B. K., Trémier, A., Martinez, J., \& Barrington, S. (2010). Home and Community Composting for on-Site Treatment of Urban Organic Waste: A Perspective for Europe and Canada. Waste Management \& Research, 28, 1039-1053. https://doi.org/10.1177/0734242X10373801

Brummeler, E. et al. (1992). Management of Organic Waste. In A. B. Sunil Kumar (Ed.), Management of Organic Waste (p. 210). Berlin: Springer.

Chynoweth, D. P. P. P. (1996). Anaerobic Digestion of Municipal Solid Wastes. In A. C. 
Palmisano, \& M. A. Barlaz (Ed.), Microbiology of Solid Waste (pp. 72-113). Boca Raton, FL: CRC Press.

Deboosere, S., Meenen, P., Boetin, D., Sudrajat, R., \& Verstroete, W. (1988). Solid Waste Fermentation with Particular Emphasis on Potentials for Developing Countries. Mircen Journal of Applied Microbiology and Biotechnology, 4, 29-36. https://doi.org/10.1007/BF00936812

Dennis Matanda, E., \& Rwandan Ministry of Infrastructure (2017). The Republic of Rwanda: Towards Universal Energy Access by 2020 in Rwanda. Clean Energy Solutions Centre.

https://cleanenergysolutions.org/sites/default/files/documents/towards-universal-energ y-access-by-2020-in-rwanda_ministry-of-infrastructure_rwanda.pdf

Greenberg, D. C., Williams, J. H., \& Ndunguru, B. J. (1992). Differences in Genotypes ICGV 86015 and ICGV 87282. The in Yield Determining Processes of Peanut (Arachis hypogaea) Genotypes in Varied Drought Environments. Annals of Applied Biology, 120, 557-566. https://doi.org/10.1111/j.1744-7348.1992.tb04915.x

Hur, J., Lee, B. M., Lee, T. H., \& Park, D. H. (2010). Estimation of Biological Oxygen Demand and Chemical Oxygen Demand for Combined Sewer Systems Using Synchronous Fluorescence Spectra. Sensors, 10, 2460-2471. https://doi.org/10.3390/s100402460

Key Note Publications Ltd (2007). Global MSW Generation in 2007 Estimated at Two Billion Tons. http://www.seas.columbia.edu/earth/wtert/sofos/Key_Global_Waste_Generation.pdf

Kigozi, R., Aboyade, A. ., \& Muzenda, E. (2014). Sizing of an Anaerobic Biodigester for the OFMSW. Proceedings of the World Congress on Engineering and Computer Science, 2, 22-24. http://www.iaeng.org/publication/WCECS2014/WCECS2014_pp659-663.pdf

Ministry of Infrastructure (2014). Sustainable Energy for All: Rapid Assessment Gap Analysis: Rwanda. Kigali-Rwanda.

Ministry of Infrastructure-The Republic of Rwanda (2015). Rwandan Energy Sector Strategic Plan (ESSP). Kigali.

https://www.mininfra.gov.rw/fileadmin/user_upload/new_tender/Energy_Sector_Strat egic_Plan.pdf

Phale, A. R. (2005). Environmental Impact and Waste Management of Used Tyres in the $R S A$. Johannesburg: The University of Johannesburg.

https://core.ac.uk/download/pdf/18220959.pdf

RDIS Organisation. (2018). Waste Management for Environmental Protection in Rwanda. Muhanga-Rwanda.

Sector, S. G. M. (2012). Analysis of Formalization Approaches in the Artisanal and SmallScale Gold Mining Sector Based on Experiences in Ecuador (pp. 1-15).

Veeken, A., Hamminga, P., \& Mingshu, Z. (2005). Improving Sustainability of Municipal Solid Waste Management in China by Source Separated Collection and Biological Treatment of the Organic Fraction. Cities.

Wellinger, A., Baserga, U. \& Egger, K. (1992). Two-Phase Continuous Anaerobic Digestion of Fruit and Vegetable Wastes. Resources, Conservation and Recycling. In W. S. Tech (Ed.), New Systems for the Digestion of Solid Wastes (p. 228). Berlin: Springer. https://doi.org/10.2166/wst.1992.0164 